\title{
PHILOSOPHICAL DIMENSIONS OF SENTENCING IN ISLAMIC CRIMINAL LAW
}

\author{
Nuraisyah \\ Fakultas Syariah IAIN Bukittinggi.nuraisyablingga@yahoo.co.id

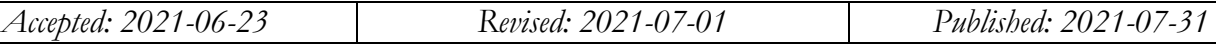 \\ (c) (7) () \\ (C)2021 by the authors. Submitted for possible open access publication under the terms and conditions \\ of the Creative Commons Attribution (CC-BY-SA) license (https://creativecommons.org/licenses/by-sa/4.0/) \\ DOI : 10.30983 /alhurriyah.v6i1.3459
}

\begin{abstract}
This study discusses about the philosophical dimensions of sentencing in terms of Islamic criminal law. Islamic criminal law has a goal that everyone does not want to commit a crime. So that Islamic criminal law is both preventive (prevention) and curative (the perpetrators of crimes are deterred by their crimes). The formulation of the problem in this study is why people who commit crimes must be punished according to Islamic criminal law? The method used is a type of normative legal research, normative legal research is a research conducted to collect and analyze secondary data. The conclusion of this study is that the provisions of the punishment contained in the Qur'an and al-Sunnah are Shari'ah that must be carried out. With this punishment, it aims to make people aware of the evils of evil, so that it is embedded in their souls that all evil must be avoided whether seen by others or not, because Allah is always watching him wherever he is. If this has been embedded in everyone, automatically evil will not exist on the surface of the earth, orat least can reduce crime in the midst of society.
\end{abstract}

Keywords: Islamic Criminal Law, Sentencing, Philosophical Dimensions

\begin{abstract}
Abstrak
Penelitian ini membahas tentang dimensi filosofis pemidanaan dilihat dari segi bukum pidana Islam. Hukum pidana Islam memiliki tujuan agar setiap orang tidak mau melakukan tindakan kejahatan. Sebingga bukum pidana Islam ini bersifat preventif (pencegahan) maupun bersifat kuratif (agar berpelaku kejahatan merasa jera dengan Tindakan kejahatannya). Rumusan masalah dalam penelitian ini adalah kenapa orang yang melakukan Tindakan kejahatan harus mendapatkan bukuman dilihat dari bukum pidana Islam? Metode yang digunakan adalah jenis penelitian bukum normatif. Penelitian bukum normatif adalah penelitian yang dilakukan untuk. mengumpulkan dan menganalisis data sekunder. Kesimpulan dari penelitian ini adalab ketentuan bukuman yang terdapat dalam al-Qur'an dan al-Sunnah merupakan Syari'at yang harus dijalankan. Dengan bukuman itu bertujuan untuk menyadarkan masyarakat dari keburukan-keburukan kejahatan, sehingga tertanam di dalam jiwa babwa semua kejahatan harus dibindari, baik dilihat oleb orang lain ataupun tidak, sebab Allab selalu mengawasinya di manapun dia berada. Apabila hal ini telah tertanam dalam diri semua orang, secara otomatis kejahatan tidak akan ada dipermukaan bumi, atau paling tidak bisa mengurangi kejahatan di tengah-tengah masyarakat.
\end{abstract}

Kata Kunci: Hukum Pidana Islam, Pemidanaan, Dimensi Filosofi.

\section{INTRODUCTION}

The law was created to regulate human life as a society, so does Islamic criminal law. The rules of Islamic criminal law come from the provisions of the Shari'ah, both those stated in the texts and those stipulated through government regulations. According to Abdul Wahab Khalaf paragraphs related to criminal
(Jināyah) only 30 verses. ${ }^{1}$ That is, the verse that prohibits an act and then is accompanied by sanctions for those who violate it is only 30 verses, in Islamic criminal law it is grouped into budūd punishment.

1 Abdul Wahab Khalaf, Ilmu Ushul al-Fiqh, (Jakarta: al-Nasyral-Majlis al-A'la Indonesia li al-Da'wah al-Islamiyah, t.th ), 33 . 
There are many more prohibitions and commands (prohibited and obligatory actions) contained in Koran verses and Hadiths but are not accompanied by sanctions for violators. According to Abdul Aziz Amir, for all immoral acts that are not accompanied by sanctions, the authority to set this model of sanctions is termed ta'zir punishment. The government is also given the authority to stipulate punishments for those who do not want to carry out the recommendations of the Shari'ah (Mandub) and leave behind (Makrub) and permissible actions (Mubah) even though their actions are not immoral, if it is to fulfill the benefit of the community. ${ }^{2}$

Islamic law in principle contains the obligation to carry out orders and leave all prohibitions. The commands and prohibitions essentially contain benefits for human life itself, both in this world and in the hereafter. Implementing Islamic criminal law is expected to minimize crime in society. If there is a violation, the consequence is that the perpetrator must be held accountable for the actions he committed in the form of punishment. Talking about crime (jināyab) means talking about worldly punishments, not ukhrawi punishments. Because there is a violation committed by a person, he cannot be punished because there is no penalty, either in the form of hadd or ta'zīr, but he is still a sinner if he does not repent for his mistake. From a religious perspective, he sinned but he was not punished. People who violate the prohibitions that have been set by Syara' are certainly sinners, but those who sin are not necessarily punished.

Everyone who commits a violation must be held accountable for his actions. Criminal offenses can be committed alone or jointly in the form of a conspiracy. If the offense is committed alone, of course he will bear the sanctions himself. It is different if the

2 Abdul Aziz Amir, Al-Ta'zir fi al-Syariah al Islamiyah, (Beirut : Dar al-Fikri al-'Arabi, 1969 ), 88. crime is committed together in the form of a conspiracy, the responsibility is of course shared as well. Because the sanctions imposed on the perpetrators of crime are not to persecute them, but to prevent crime from running rampant on the surface of the earth. To describe the concept of Islamic crime and anticipate that the crime rate will always decrease, it is even hoped that Islamic criminal sanctions can eliminate crime in the society.

For this description, the author tries to present it in a discussion with the title: "Philosophical Dimensions of Criminal Justice in Islamic Criminal Law" This paper only reveals the concepts of Islamic criminal law regarding legal sanctions for perpetrators in order to avoid crimes / violations that can harm others.

This research has a problem formulation: why do people who commit crimes have to be punished according to Islamic Criminal Law?

The type of research conducted is normative legal research, normative legal research is research conducted to collect and analyze secondary data. Analyzing secondary data by taking data from secondary sources, namely research results, papers and journal. ${ }^{3}$

\section{DISCUSSION}

Humans as creatures of God are equipped with lust and ambitions that have the potential to give birth to conflict. Human efforts to meet the needs of a competitive life always intersect with association with other people, it can even give birth to violations related to God's rights or related to human rights. In fact, it is not uncommon to achieve this ambition by involving other parties in committing crimes/violations.

\footnotetext{
${ }^{3}$ Fitri Wahyuni, Sanksi Pidana Pemerkosaan terhadap Anak menurut Hukum Pidana Positif dan Hukum Pidana Islam, Jurnal Media Hukum, Vol. 23, No. 1, Juni 2016, 98.
} 
The existing regulations in Islamic criminal law exist to anticipate crimes that occur in society, although there are pros and cons to the punishments listed in it. There are those who think that criminal sanctions in Islam are too cruel and harsh, on the other hand there are those who think that severe sanctions can be a solution to reduce the occurrence of crimes. This discussion begins by revealing what is a crime/violation according to Islamic criminal law.

\section{Definition of Crime}

Human actions that are judged as crimes or violations among each other are discussed in jināyah, whether physical or non-physical crimes, which are related to material or nonmaterial things such as crimes against life, body, belief, a person's good name and others that have the potential to bring harm. In Islamic criminal law, there are two terms related to criminal discussion, namely: aljināyah and al-jarīmah.

\section{a. Al-jināyah}

Jināyah means sins, mistakes and crimes. Jināyah is the noun (mashdar) of janaa ( $f^{\prime} i l$ madhi/past tense). Abdul Qadir Audah stated that jināyah according to Islamic Shari'ah is an act that is prohibited by Syara', whether it threatens the safety of life or property. ${ }^{4}$ In the Hanafi school of fiqh, jināyah is a discussion of the sin of violating one's life. While the sin of violating property is discussed in the chapter al-ghashab. However, most jurists use the term jināyah for acts whose targets are related to the soul of a person (murder) and criminal acts of persecution (injuring, hitting, abortion). So the discussion of murder and persecution is put forward in chapters al jinayaat and aljarh or aldharb. However, there are also jurists who equate the term jināyah with jarimah, in the context of criminal acts, because it conforms to positive criminal law

4 Abdul Qadir Audah, Al-Tasyri' al-final al-Islami, (Beirut: Muassasah al-Risalah, 1992 ), juz.1, 66. which does not recognize the terms hudūd, qishash/diyat and ta'rir.

\section{b. Al-Jarimah}

An act is called jarimah if the act results in harm to other people or the community both related to soul/body, property, security, rules, good name, feelings and other things that need to be protected. The term jarimah comes from the words: jarama, yajrimu, jarimatan means al-zanbu (sin, mistakes and crime). Al-Mawardi put forward the definition of jarimah as follows: Jarimah are syara' probibitions which are threatened with hadd and ta' 2 ir punishments. ${ }^{5}$ According to Muhammad Salim al-'Awa, jarimah is doing or leaving what has been determined by the syara' regarding the probibition and legal sanctions for the perpetrators. ${ }^{6}$

Syar'a prohibitions (mahzhürät) There are two types in the definition above, namely:

1. Ityānu fi'li al-manbi anh (doing prohibited acts).

2. Tarku fi'li al-ma'müri bih (not doing what's ordered).

The prohibition of doing and the prohibition not doing an act has been determined by syara'. This can be seen from the words "syar'iyah" contained in the definition above that the prohibitions are derived from syara'. If there is a violation of the criminal rules stipulated by Syara', they are threatened with punishment, either punishment hadd atau punishment ta'zir.

Hadd punishment is a punishment that has been determined by the type and amount by Syara' and is the right of Allah. The point is that the punishment that has been determined in terms of the amount and type does not have a lower and upper limit. All hadd punishments are the right of Allah, meaning that they cannot be overturned either by individuals or

${ }^{5}$ Al Mawardi, Al-Ahkam al-Sulthaniyah, ( Mesir : Mustha al-Bab al-Halabi, 1973), 219.

6 Muhammad Salim Al-'Awa, Fi UshulalNizham al-Jinaai al-Islami ( Mesir : Dar al-Ma’arif, 1983 ), 126. 
by society. The punishments included in the rights of Allah are any punishments that are desired to maintain the public interest. Where the benefits of sentencing can be felt by the whole community without distinguishing one another.

Among the hadd punishments there are also those which are individual rights. That is, the victim (majniy 'alaih) or his guardian has the right to abort the punishment that has been determined by the type and amount by syara'. In principle, this kind of punishment applies to crimes of murder and persecution crimes, such as qishash and diyat.

Ta'zir punishment is a punishment that is not determined by the type and amount by Syara' for each particular crime and violation. Syara' only mentions a set of punishments ranging from the lightest to the most severe. Syara' gives freedom to judges to choose the appropriate punishment for the criminal act committed by a person. The purpose of granting the right to freedom in determining and choosing sentences to judges is so that they can regulate and maintain the interests of their community in accordance with the development of the community itself.

From the explanation above, it appears that the use of the word jināyah with jarimmah is synonymous. However, in its use, the term jināyah in fiqh books is more directed to the discussion of the crime of murder and persecution. While the use of the term jarimah is more directed to the discussion of hudūd crimes (zinā, qåf, sirqah, syurbu al-khamr, biräbah, baghyu and riddab).

When these two terms are associated with positive law (criminal law in Indonesia), the term jināyah is synonymous with criminal law (rules of crime and violations).

Meanwhile, the term jarimah is synonymous with offense or crime. Thus it can be said that the term jināyah is more commonly used than the term jarimah. Because all the objects of discussion about jarīmah always start from jināyah. Not all talk about jināyah, which ends with a discussion of jarimah. The rules that the finger talks about are the rules that stipulate prohibitions and punishments. Talks about jināyah always start with the prohibition, but not all prohibitions talk about punishment (sanctions). So jināyah focuses more on the names for forbidden acts, while jarimah relates to violations of forbidden rules that have sanctions provisions in the world.

\section{Elements of a Crime}

In Islamic criminal law, there is no distinction between offense and crime, all of which are grouped under jināyah or jarīmah. An act can be considered as a finger if it harms the lives of members of the community both related to objects, good names, beliefs and so on. To prove that a loss has occurred, of course it is seen whether the perpetrators can be categorized as those who can be prosecuted legally or not. In this case, the elements of a crime must be fulfilled, both general elements and special elements.

As mentioned in the definition of jarimah before, criminal acts are syara' prohibitions which are threatened with hadd punishment or ta'zir punishment. The prohibition is sometimes in the form of an act or not doing an action. Then it was also determined that the person who made the prohibition was Syara' which was imposed only on those who could account for it in the form of hadd punishment or ta'zir punishment. For this reason, Islamic criminal law when discussing the elements of a criminal act, the general elements and the particular elements are always stated. General elements are elements that must exist in all criminal acts. If one of them is missing, then the crime does not occur legally. While special elements only 
apply to certain criminal acts. The general elements of Islamic criminal acts are :

a. Al-Rukn al-Syar'í or legal elements, namely texts that prohibit an action and texts that stipulate penalties for people who violate the prohibition. In positive law this element is called a formal element. This element is a manifestation of legal certainty, therefore Islamic criminal law must stipulate:

1. Every criminal regulation must clearly state the form of the crime, so that the public knows for sure the actions that must be avoided.

2. Every criminal law must include the form of sanctions for the crime, so that the public knows the punishment they will receive if violated.

3. Each of these criminal rules guarantees the harmony of society.

The legal provisions that stipulate the existence of this element in Islamic punishment can be seen in the word of Allah in the letter al-Isra' verse 15 below: And We will not punish until We send a Messenger. (Q.S.17: 15).

Discussions that are closely related to alrukn al-syar'i are: the sources of Islamic criminal law, the principles of Islamic criminal law, the interpretation of Islamic criminal rules and the environment in which Islamic criminal law applies. All of these topics will be discussed in separate chapters and chapters.

b. Al-Rukn al-Mādì behavior that forms the occurrence of criminal acts, whether in the form of real actions or attitudes of not doing. This element is also called the material element in positive law.

The provisions for the existence of this element in Islamic punishment can be seen from the following hadith of the Prophet: From Abi Hurairah r.a, the Messenger of Allah said:

7 Lysa Angrayni, Hukum Pidana dalam Perspektif Islam dan Perbandingannya dengan Hukum Pidana di Indonesia, Jurnal Hukum Islam, Vol. XV, No.1, 2015, 50.
Verily Allah forgives or is triggered by someone as long as he does not do or utter words. ( HR. Tirmizi ). ${ }^{8}$

Discussions that are closely related to alrukn al-madi are: the various types of Islamic crimes from various angles of review, criminal trials, criminal inclusion, will also be discussed in a separate chapter.

c. Al-Rukn al-Adabi namely elements related to people who can be held accountable for crimes they have committed. This element is also known as the moral element in positive law.

The determination of this element can be seen from the following hadith of the Prophet: "And Aisyah ra, Rasulullab $S A W$ said: (sins) are forgiven for my ummah from three things, namely: and young children until they reach puberty, people sleep until they wake up and from crasy people until they are bealtby " (HR Tirmizi ).

Discussions related to al-rukn al-adabi are: criminal liability, the level of accountability and the abolition of criminal liability as well as matters relating to the punishment that will be borne by criminals. It will be described in a separate chapter in the following discussion.

These three elements must be found in all criminal acts without distinguishing one another. In addition to these general elements, there are also special elements in each jarimah (criminal act) which differ from one crime to another. This difference arises due to the different nature of the crime committed by a person. The Fuqaha' usually talk about this particular element when discussing the subject matter of these kinds of crimes.

In Islamic criminal law, a distinction is made between the punishments set by Syara' and those determined by Ulil Amri, which are known as hadd punishments and ta'zir punishments. There are four principles that distinguish between hadd punishment and ta'zir punishment, namely:

8 Al.Tirmizy, Sunan al-Tirmizi, (Mesir: Musthafa al.Babi al-Halaby, 1968 ), 89.

${ }^{9}$ Al-Tirmizi, Sunan Tirmizi, 32. 
Firstly, in terms of the right to forgive punishment :

1. Hadd punishment is the right of Allah, no one can forgive and forgive the punishment stipulated in the texts. If the crime has been proven, the judge must impose a sentence in accordance with the paragraph, for this reason, amnesty, pardon and abolition do not apply to hudūd crimes.

2. In the case of qishash/diyat, forgiveness can be granted by the victim. Forgiveness given by the victim can affect the punishment that will be received by the perpetrator. The victim can forgive the gisbash sentence and change it to a diyat sentence, and also the victim can release the perpetrator and the diyat sentence. In this crime, the head of state does not have the authority to pardon, because the right to pardon is only owned by the victim or his guardian. Except, if the victim is not capable of taking legal action and does not have a guardian, then the head of state will be the guardian.

3. For the ta'zir crime, the head of state has full authority to release the perpetrator or the punishment, provided that it does not interfere with the personal rights of the victim. Likewise, the victim has the right to grant forgiveness to the extent that it relates to his personal rights, and is not related to the rights of the community. In this crime, the head of state has the right to amnesty, pardon and abolition.

Secondly, in terms of the power and authority of judges.

1. For budūd crime, if the act has been proven, the judge must carry out and apply the punishment that has been determined by the texts for the crime concerned without reducing, adding, delaying or replacing it with other punishments. The judge's room for movement is very limited only to proving and deciding then carrying out the punishment that has been stipulated in the texts

2. For the qishash/diyat crime, the judge's authority is to prove whether the criminal act was carried out by planning or not. Then pass a verdict based on the evidence. Meanwhile, to carry out the sentence is the authority of the victim with the supervision of the judge. Punishment can be carried out based on the recommendation of the victim or his guardian.

3. For the $t a$ 'zir crime, the judge's authority is very broad. Judges have full authority to determine whether someone's actions are criminal or not, whether or not someone is punished for their actions and the judge has the right to incriminate, relieve and postpone the punishment received by the perpetrator.

Thirdly, In terms of conditions that can lighten the sentence.

1. For budūd crimes, there are no conditions that can ease the punishment for the criminal, if the act has been proven.

2. For qishash/diyat, there are no conditions that can ease the punishment.

3. In the case of $t a^{\prime}$ 'zir, the condition of the criminal offender can reduce and affect the punishment for the criminal, either for the crime someone committed or for the punishment someone has received.

Fourthly, In terms of the burden of evidence.

1. For the crime of budūd, syara' has determined the evidence that must be met in determining a criminal act, such as: confessions and four witnesses for the crime of adultery, two witnesses for the crime of kazaf and others. 
2. In qishash/diyat crime, the evidence used for the formal truth of the murder has also been determined, such as a confession, two witnesses and a qasamab.

3. In the case of $t a^{\prime}$ ' $i r$, the evidence is not fixed permanently. Syara' gives tolerance for judges to use evidence that can prove the formal and material truth of the ta'zir act, such as allegations, letters and others.

From these four differences, it can be seen that the hadd punishment looks harsh, but the severity of the hadd punishment will have a positive impact in preventing crime.

\section{Philosophical Aspects of Criminal Justice in Islamic Criminal Law}

Wahbah al-Zuhaili stated that the purpose of the punishment was : ${ }^{10}$

a. Preventing and providing a deterrent effect.

The punishment has two functions, namely for the perpetrator and for others. Giving punishment to criminals can provide a deterrent effect so that they do not repeat the same act. Because if they did it again they would receive the same punishment again. Then the punishment also serves to prevent others from committing the same act because if someone commits the same act they will also receive a punishment like the punishment imposed on the perpetrator of the crime. Thus, the punishment has a major contribution to suppress the rate of crime in society, so that people can be protected from crime.

b. Repairing, rehabilitating, Restoring and straightening.

One of the purposes of imposing punishment on criminal offenders is to improve and straighten mental awareness while at the same time convincing the perpetrator of the mistakes they have made. The punishment also protects the public from

10 Wahbah Zuhaili, Al-Fiqh al-Islami wa Adillatuh, ( Damsyiq, Dar al-Fikr, 1983 ), 270 - 276. the bad habits of criminals. Al-Mawardi said that the punishment given was to discipline, correct and reprimand the perpetrator for the wrong he did. ${ }^{11}$

c. Fighting Crime.

In the nature of things, crime causes harm to society, therefore it must be eradicated. Crime is like a plague that can spread everywhere if it is not contained and eradicated. One way to eradicate it is to punish the perpetrators so they don't spread to other people.

d. Curbing anger from victims and their relatives

The desire for revenge is one of human nature. Various circumstances will give birth to new crimes, in fact it can become a hereditary revenge. Sentencing the perpetrator according to the crime he committed can reduce the anger of the victim or his guardian, because he feels that his crime has been avenged with the punishment given, so that the victim or his guardian is satisfied with the punishment without any desire for revenge. ${ }^{12}$

Abdul Aziz Amir said that the purpose of the punishment was:

1. Al-Rad'u wa al-Zajru (preventing and giving lessons) for the perpetrator not to repeat the same act and not to commit a crime for a long time. In addition, the punishment also aims to prevent other people from committing similar acts, because if he does, of course he will also receive a similar punishment.

2. Al-Ishläh wa al-Tabzìb (correcting and educating) The second purpose of giving punishment to criminals is to educate the perpetrator so that he becomes a good person and always avoids mistakes. With the punishment, it is hoped that the perpetrator's awareness will arise to

11 Al-Mawardi, Al-Ahkan al-Sulthaniyah, 223.

12 Hamzah Hasan, Kontekstualisasi Teologi Keadilan dalam Hukum kisas, Jurnal Al Qadau, Vol. 1 No.1, 2014, 86. 
stay away from crime not only because of the knowledge of punishment, but because of his hatred of crime and getting favors from Allah SWT. ${ }^{13}$

According to Siti Jahroh that the purpose of imposing sanctions for criminal offenders is the realization of the objectives of Islamic law itself, namely as retaliation for evil deeds, prevention in general and prevention in particular as well as protection of the rights of victims. ${ }^{14}$

\section{The potential of Islamic Criminal Law in Minimize Crime}

As previously explained, the purpose of Islamic punishment is in line with the purpose of human life, namely to achieve happiness in life in this world and the hereafter. To achieve this goal, there are many things that must be done and that must be avoided. The actions that must be done in fiqh are called obligations and those that must be avoided are also obligations to leave them. If it is done, the sin will be accepted later in the hereafter. However, there are some actions in addition to receiving rewards in the hereafter, in this world the punishment is also carried out either in the form of hadd or in the form of ta'zir punishment Hadd punishment is a punishment that Allah has ordained through His word. Hadd punishment is only intended for seven types of crimes (zina, qazaf, sariqah, harabah, baghyu, syurbu al-khamri and riddah) and includes crimes of murder and persecution. All these crimes have provisions for the form and level of punishment and are a family of punishments in Islamic criminal law. In principle, hadd punishment is the maximum punishment that cannot be changed, aborted and suspended, because it is the right of Allah that must be carried out. On

13 Abdul Aziz Amir, Al-Ta'zir fi al-Syari'ah alIslamiyah, 293-299.

14 Siti Jahroh, Reaktualisasi Tiori Hukuman dan Hukum Pidana Islam, Jurnal Hukum Islam, Volume 9, Nomor 2, 2011, 2. the other hand, there is also a ta'zir punishment in which the determination of the form and level is left to the government, with the aim that the government can adjust the punishment to be received by the perpetrator according to the crime he committed.

Hadd punishment looks harsh, but the severity of hadd punishment will have a positive impact in preventing crime. Because after all ideally a regulation if it is not accompanied by adequate sanctions, then the regulation is less effective to be obeyed. Hadd punishment that Allah has set to be applied in this world is not based on the size of the crime committed, but based on the benefits for humans, who knows the nature of the benefit of the punishment is Allah SWT. Based on that, Allah SWT enforces His laws. The determination of hadd punishment may not be based on the size of the crime with certain standards, but must be based on the provisions contained in the Nash, not based on ijtihad. This is in accordance with the rules of Islamic criminal law, la jarimata wa la uqubata illa bi nash (There is no crime and punishment unless it must be based on the texts). ${ }^{15}$

In contrast to ta'zir punishment, its existence is rather flexible, it is possible to change the form and level of punishment with changes and changes in leaders. The punishment determined by a country called positive law is categorized as ta'zir punishment. This form of punishment is recognized by Islam in accordance with the definition of jarimah that has been stated above. In other words, in Indonesia, Islamic criminal law has been applied in the form of ta'zir punishment. While the new hadd punishment applies based on the faith of each adherent, not yet constitutionally. Therefore, if there is a crime related to the hudūd crime, the hadd punishment cannot be carried out because the implementer of this punishment

15 Abdul Qadir Audah. Al-Tasyri' al-jinaai alIslamiy, 118. 
has not yet been formed. But that does not mean that Muslims do not recognize the hadd punishment. This happens because the criminal law is included in public law, and public law is left to the state to implement it. This is in line with the following rules: From Ali $\mathrm{R} A$, be said : Avoid carrying out budūd punishments if doubts are found (HR. Baihaqi ). ${ }^{16}$

If the hadd punishment cannot be implemented because the legal apparatus has not been given the authority to carry it out, then the punishment for the perpetrators of the crime is carried out based on the authority given to the legal apparatus. The authority given to legal instruments in Indonesia is only limited to carrying out punishments that have been promulgated by the state which are grouped into ta'zir punishments in Islamic crimes. Enacting the ta'zir law means that Islamic criminal law has been implemented. This is better than not punishing the criminals at all. Because punishing the perpetrators of crimes is not aimed at torture, revenge, inflicting harm on them. However, the desired goal in Islamic Shari'ah is to prevent, threaten, correct, straighten and provide a deterrent effect to the perpetrators. If by giving light punishments to the perpetrators the purpose of punishment has been achieved, then there is no need to apply heavy penalties, and it does not mean that hadd punishments are not recognized by Indonesian Muslims. Actually, what is required from the implementation of the criminal code is to instill confidence in its adherents so that everyone hates crime, so that he avoids the act whether it is seen by others or not, because he knows that Allah sees what he is doing. If he commits a crime he is sure that he will receive his reward in the hereafter in the form of sin that plunged him into hell even though in this world he escaped punishment.

${ }^{16}$ Muhammad bin Ismail al-Kahlani, Subul alSalam, (Bandung : Dahlan, 1959), 15.
The wisdom behind hadd punishment and ta'zir punishment in the Shari'a of Allah SWT has clear aims and objectives, namely straightening, correcting, and rehabilitating the behavior of the perpetrator. Crime, giving it a deterrent effect and preventing it from repeating its crime, providing a deterrent effect and fear for others so that they do not commit these crimes that disturb security stability and public benefits, protect the community from various forms of chaos and damage, cleanse the soul - a soul who deviates from the stains of sin and disobedience that pollutes and contaminates the clarity of the heart and the sanctity of the soul, strengthens conscience, increases sharpness of heart and human feelings to protect and respect the rights of others, and keep away from various forms of harmful actions and detrimental. It is said that the punishment is an aspect of retaliation in Islamic punishment based on the word of Allah in the letter al-Maidah verse 38 below: The man who steals and the woman who steals, cut off their hands (as) in retribution for what they did and as a punishment from Allah. And Allah is Mighty, Most Wise (QS : 5, 38)

This verse explains that the person who steals has his hand cut off in return for the crime of theft he has committed. Likewise the punishment for the perpetrators of murder and persecution, that the crime of murder and persecution is also a retribution for their crimes by punishing them as they did to the victim. This is explained in the word of Allah as follows: O you who believe, qishas is prescribed for you with regard to those who are killed; free man for free man, servant for servant, and woman for woman (QS : 2, 178).

In essence, the purpose of Islamic Shari'ah to impose punishment on criminals is to awaken people to hate crime. With this awareness, it is hoped that the punishment in Islamic criminal law, whether in the form of hadd or ta'zīr, can be a tool to eradicate crime. whether he is known by others or not, or he 
can escape from being chased by the authorities or not, but in the end he will not be able to escape the punishment of the hereafter.

Signs that the punishment can prevent the perpetrator from committing a crime can be proven by:

a. Immediately stop from doing crimes that cause sin for the actions he has done.

b. Determined not to do it again in the future forever.

c. Determined to free himself from his evil past.

Then the punishment also serves to prevent other people from doing the same thing because if he does the same thing he will also receive the punishment. On the other hand, the punishment also shapes society to be good, because they respect each other, love each other.

By knowing the limits of their rights and obligations. In essence, crime is an act that is not liked, tramples on justice and arouses public anger against the perpetrator, on the other hand, people feel pity for themselves and pity for their victims. So with the punishment of the perpetrators of the crime, the people feel relieved because justice has been achieved. Thus it can be said that if the purpose of punishment has been achieved, then Islamic criminal law did a very important role in eradicating crime.

\section{CONCLUSION}

Based on the discussion that has been disclosed above, it can be concluded that the provisions of punishment contained in the Qur'an and al-Sunnah are Shari'ah must be carried out. The punishment aims to awaken people from the evil wrongdoings, so that it is embedded in their souls that all evil must be avoided whether seen by others or not, because Allah is always watching them wherever they are. If this has been embedded in everyone, automatically evil will not exist on the surface of the earth, or at least can reduce crime in the society.

\section{BIBLIOGRAPHY}

Al-'Awa,Muhammad Salim, Fi Ushulal-Niæ̌ham al-Jinaai al-Islami, Mesir, Dar al-Ma'arif, 1983.

Al-Kahlani, Muhammad bin Ismail al-Kahlani, Subul al-Salam, Bandung, Dahlan, 1959 .

Al-Mawardi, Al Abkam al Sulthaniyyah, Mesir, Musthafa al-Babi al-Halabi, 1973.

Al-Nawawi, Imam, Al-Majmu' Syarh al-Mubazzab, juz 21, Beiru: Dar al-Fikr, 1996.

Al-Ramli, Nihayah al-Mubtaj Ila Syarh al-Minhaj, jilid 5. Beirut: Dar al-Fikr, 1983.

Al-Syairazi, Al-Muhazzab, juz 3. Mesir: Isa al-Babi al Halabi, t.th.

Al-Syaukani, Muhammad Ibn Muhammad Ibn Ali, Nail al-Authar, Juz. VI \& VII, Mesir, Musthafa al-Babi al-Halabi, t.th.

Al-Syuyuthi, Jalal al-Din, Al-asybah wa al-Nazha'ir, Semarang, Toha Putra, t.th.

Al-Tirmizy, Sunan al-Tirmizi, Mesir, Musthafa al.Bab al-Halaby, 1968.

Al-Zuhaili, Wahbah, Al-Fiqh al-Islami wa adillatubu, Juz.VI, Beirut, Dar al Fikr, 1989.

Amir, Abd. Al-Aziz, Al-Ta'zir fi al-Syari'ah al-Islami, Beirut, Dar al Fikr, 1969.

Audah, Abd. Al-Qadir, Al-Tasyri' al-jina'I al-Islami, Juz.I \& II, Beirut, Muassasah al-Risalah, 1992.

Fitri Wahyuni, Sanksi Pidana Pemerkosaan terhadap Anak menurut Hukum Pidana Positif dan Hukum Pidana Islam, Jurnal Media Hukum, Vol. 23, No. 1, 2016.

Hamzah Hasan, Kontekstualisasi Teologi Keadilan dalam Hukum kisas, Jurnal Al Qadau, Vol. 1 No.1, 2014.

Jahroh, Siti, Reaktualisasi Teori Hukuman dan Hukum Pidana Islam, Jurnal Hukum Islam, Volume 9, Nomor 2, 2011.

Lysa Angrayni, Hukum Pidana dalam Perspektif Islam dan Perbandingannya dengan Hukum Pidana di Indonesia, Jurnal Hukum Islam, Vol.XV, No.1, 2015. 
Marsaid, Al-Fiqh al-Jināyah ( Hukum Pidana Islam) Memahami Tindak Pidana dalam Hukum Islam, Palembang: Rafah Perss, 2020.

Otoberinsyah, Tujuan Pemidanaan Dalam Islam, Jurnal Agama dan Hak Azazi Munusia, Vol. 7, No. 2, 2018.

Rusyd,Ibn, Bidayah al-Mujtahid wa al- Nihayah al-Muqtashid, jilid 1, Mesir: Mustafa al-Babi al-Halabi, 1960.

Zahrah, Muhammad Abu, Al-Jarimah wa al-uqubah fi al-Fiqh al-Islami al-Uqubah, Beirut: Dar al-Fikr, t.th. 